DOI: $10.30519 /$ ahtr.536303

Advances in Hospitality and Tourism Research (AHTR)

\title{
THE EFFECTS ON CONSUMER BEHAVIOR OF HOTEL RELATED COMMENTS ON THE TRIPADVISOR WEBSITE: AN ISTANBUL CASE ${ }^{1}$
}

\author{
Emrah Sitk1 YILMAZ 2 \\ Gaziantep University, Turkey \\ ORCID: 0000-0003-2741-4222
}

\begin{abstract}
In parallel with the major developments witnessed in information technologies, social media, supported by its broad area of usage, is gaining significance in every field, with the tourism sector being no exception in this regard. The transfer of changing marketing strategies via digital channels into social media has transformed the way customers interact with the tourism sector, having now the ability to access the comments of other consumers via social media, and adjusting their preferences accordingly. In this study, the impact of the content analysis on the star rating given to hotels is examined with a "Panel Data Analysis" of all the hotels in Istanbul that have received a maximum of 25 reviews on the TripAdvisor website, with a total of 12,000 comments assessed. It was found that the location of the hotel, the access to transport facilities, the food and beverage concept, the quality of staff/service, and the cleanliness of the facilities all affected the star ratings given to hotels; while the architectural structure and the recommendations of other guests had a lesser effect. It was further noted that entertainmentanimation programs had little effect on guest preferences.
\end{abstract}

\author{
Article History \\ Received 6 March 2019 \\ Revised 16 July 2019 \\ Accepted 22 July 2019 \\ Keywords \\ TripAdvisor \\ social networking sites \\ Istanbul \\ panel data methodology \\ consumer comments \\ tourism sector
}

\footnotetext{
${ }^{1}$ This manuscript is based on dissertation research of the author at the Department of Business Administration, Gaziantep University.

${ }^{2}$ Address correspondence to Emrah Sitk1 Yilmaz (PhD), Gaziantep University, Gaziantep, TURKEY.

E-mail: esyilmaz@gantep.edu.tr
} 


\section{INTRODUCTION}

In parallel with the technological developments around the world in recent years, the means by which we "access information" have changed dramatically, leading to changes in the way people make their purchasing choices. These changes in the accessibility of information have affected institutions and consumers' alike, and social networking has added a distinct dynamism to communication, raising the importance and increasing the scope of "blogs" and the mutual exchange of information. Such outlets of information can provide ideal opportunities for the marketing, branding, development and positioning of products, for increasing corporate reputation, for the making of market researches and for the evaluation of customer feedback. At the same time, such blogs can aid consumers in identifying their needs, allowing an analysis of their alternatives and guiding the other consumers together with the evaluation stages after the exchange of traditional information (Mazzarol et al., 2007; Nardi et al., 2007; Gretzel \& Yoo, 2008; Sweeney et al., 2008; Howe, 2009; Deng et al., 2014).

For customers of the tourism and hospitality sector, acquiring information and making purchasing decisions based on this information can be realized in the easiest and fastest way through the comments and information provided by social networking sites (Liu \& Park, 2015). The rapid advances in information technologies have led to significant changes in the global tourism and hospitality sector, and today, consumers can turn to such resources as TripAdvisor - one of the leading blog sites influencing tourism preferences -to quickly access data about hotels. This puts them at the very center of these organizations, and these sources provide significant opportunities not only to consumers, but also hotels, having become a key component of the tourism sector (Buhalis \& Law, 2008; Litvin et al., 2008; Lee \& Youn, 2009; Stringam \& Gerdes Jr, 2010; Neuhofer et al., 2012; Leung et al., 2013; Ladhari \& Michaud, 2015).

As trip planners lack a general criterion for the measurement of a tourism experience on which to base their purchase decisions, they need the opinions and comments of users with previous experience of their planned destinations, and therefore often consider pre-travel inspections, since it is impossible to experience every aspect of the destination prior to making a purchasing decision. Accordingly, content created by users plays an important role in the creation of a brand and image, as well as in target awareness and choice (Mazzarol et al., 2007; Gretzel \& Yoo, 2008; Sweeney et al., 2008). The increasing number of contributors to social 
networking sites and blogs has emerged as a means of better understanding consumer behavior, allowing enterprises also to increase their sustainability and strengthen their brand (Hashim \& Murphy, 2007; Levy et al., 2013). Digital platforms such as social networking sites and blogs serve as an active platform for the exchange of information between the guest and the hotel and business manager; permit the evaluation of customer comments, reviews and suggestions; provide an opportunity to build trust and recognition; and give businesses the opportunity to correct negative customer experiences, while also facilitating the development of brand perception, providing access to a large customer information network and allowing the consideration of consumer feedback prior to the development of new products or services (Baird \& Parasnis, 2011; Sigala, 2012; Rosario et al., 2013).

Within the modern marketing concept, the expected effects on online consumer behaviors occur spontaneously as a result of efforts to gather the necessary information to meet demands and needs in the best possible way, to evaluate this information and to understand all aspects of consumer behavior, based on the comments and reviews made by guests after making a purchase. Online consumer behaviors are considered as conceptual conscious consumers in the concept of contemporary marketing, and are defined as the power of information, researching information, sharing of information results and the power of information technologies by determining the needs of consumers, meeting their needs and specifying positive or negative comments after the purchase. From this perspective, social networking sites and blogs can directly influence how consumers make their purchasing decisions, making use of online environments and the shared opinions and comments of others, thus giving power to consumer behavior patterns by directly affecting consumer behaviors (Constantinides \& Stagno, 2011; Yilmaz, 2017).

For Turkey, where the tourism sector is the leading source of income, the number of tourists visiting the country is very important (Turkish Statistical Institute, 2018). As one of the largest and most touristic cities in Europe, and the only city in the world that is located on two different continents (Europe and Asia), Istanbul has significant tourism potential in terms of historical tours, shopping, world cuisine and nightlife, and is one of the leading cities in Turkey's tourism sector. Following a rising trend since the beginning of the 2000s, and hosting $39,488,401$ foreign visitors in 2018, Istanbul was still Turkey's most visited city in 2018, with 13,729,747 guests (Turkish Statistical Institute, 2018). The city has been able to increase its value as a tourism destination thanks to 
the presence of hotels appealing to all tastes. Due to the advantages they bring and the dynamic role they play in Turkey's tourism sector, digital travel platforms like TripAdvisor, and the details they provide of the products, services and accommodation provided by the many different types of hotels, are very seriously by the sector in Istanbul. The city also pays close attention to the comments, reviews and suggestions made on such platforms, and addresses almost all of the positive or negative comments made on these sites by adjusting the provided services accordingly. Advanced blog sites such as TripAdvisor have filled an important gap in the market for consumers when making their choice of destination, with significant reliance and emphasis placed on consumer comments (Park \& Kim, 2008; Gretzel \& Yoo, 2008).

This study assesses how the opinions and comments made about hotels on TripAdvisor, as one of the leading tourism-related blog sites, affect consumer behaviors, and the criteria determined by the content analysis based on these interpretations. The study also looks into how potential guests have an impact on hotel preferences. For the study, the 25 hotels that have attracted the most comments by consumers on the TripAdvisor site, are identified, with a total of 12,000 comments about these hotels analyzed. The results of this analysis have been used to determine the criteria for specific subheadings. The study further makes a panel data analysis to examine the impact of these criteria on the hotel preferences of consumers for a four-year period. Determining these impacts, it is believed, will make a significant contribution both to the hotel sector and the body of tourism literature.

The contributions of this study to the existing body of literature are threefold. First, this is the first study to investigate the determinants of tourist hotel preferences by making use of an econometric approach. Second, the hotels are evaluated in whole sample, which leads to more consistent findings than previous studies due to the adopted panel data methodology. Third, this study examines tourist preferences based on seven different criteria (architectural structure of the hotels, general cleaning services, food and beverage concept, personnel and service quality, entertainment and animation services, location and transportation facilities, and the ranking of the hotel, as scored by other users), providing clear data on consumer preferences that can be used by hotels to steer policy and strategies to attract more guests. 


\section{LITERATURE REVIEW}

With the spread of the Internet and developments in communication technologies, new platforms affecting living spaces are emerging. These platforms are growing with the inclusion of people in social groups and virtual communities on the Internet, resulting in a shift in the knowledge economy toward the production of information by consumers. Social networking sites that prioritize these platforms, and that eliminate the boundaries between the producer and consumer, are able to increase their institutional capital day-by-day through the use of cheap technological tools (Howe, 2009; Yamamoto \& Şekeroğlu, 2014).

Most blogs serve as places where people put down their thoughts in the way they want, and as a branch of social networking, offer a means of mutual communication where individuals can make comments and receive online responses at any time. The ability to respond to these online comments by consumers and institutions with the desire to do so makes blogs an important element in marketing in terms of the transfer of capital strength to the consumer (Williams \& Jacobs, 2004; Seyrek \& Yilmaz, 2016).

The history of blogs dates back to 1997, and their creation has been attributed to Internet author John Barger. The term "blog" is derives from the "Weblogs", being defined as "Logs created in a web or Internet environment". Blogs have been defined as "free lecture" environments in view of their structure in which the writer and reader are free to express their opinions. They have been referred to also as "virtual media diaries", with posts displayed in reverse chronological order to ensure that the most recent contents can be seen and read easily. Blogs have further been described as learning-oriented structures in which text, links, images, and audio and video recordings can be uploaded, as well as being an environment where news can be gathered, various Internet links can be provided, and users can write whatever they want, resulting in a constantly updated platform (Prensky, 2001; Bausch et al., 2002; Williams \& Jacobs, 2004; Boyd \& Ellison, 2007; Murugesan, 2007; Ostrander, 2007; Eley \& Tilley, 2009; Seyrek \& Yilmaz, 2016).

Blogs that have the capacity to involve people in collaborative activities and information sharing have become an important source of information in every field, and the tourism sector is no exception (Williams \& Jacobs, 2004; Werthner \& Ricci, 2004). The increase in the online exchange of travel information has allowed tourists to consider many options when searching for a suitable hotel. In this context, since 
blogs take on the task of collecting information, archiving such as information retrieval and comparison, and shaping the tourism industry, tourism activities are affected more by other sectors (Bausch et al., 2002; Pan et al., 2007).

Playing an important role in shaping the tourism sector and making use of advanced technologies, travel blog sites provide consumers with important data that can steer their purchasing habits, and particularly the comments of previous users highlighting the strengths and weaknesses of hotels, based on their first-hand experiences. Every year, the increasing number of people with tourism mobility and the wealth of available information on the tourism sector have made the use of the most reliable and well-known of the blog sites almost obligatory. TripAdvisor and similar blog sites operating in the tourism sector serve as an important source for the evaluation of consumer preferences in tourism, given their growing coverage. Through the comments and evaluations posted by consumers, TripAdvisor has a great deal of influence over potential guests, and as a result, its standing among the blog sites that are active in the field of tourism. The shared tourism experiences in the form of comments on advanced blog sites such as TripAdvisor allows us to better understand the dynamics in the sector, and offers significant potential to businesses and managers, while also guiding potential guests in their purchasing decisions (Jeong \& Jeon, 2008; Zheng et al., 2009; Sparks \& Browning, 2010; Stringam et al., 2010; Limberger et al., 2014; Molinillo et al., 2016).

TripAdvisor was established in the United States in 2000, and has grown to become one of the largest and most popular online travel resources in the world (Law, 2006). The site serves as a message board for content created by users focusing on accommodation and travel, and has grown into a platform listing approximately 7.7 million registered tourism enterprises that have been subjected to over 661 million evaluations. Some 456 million people on average visit the site every month, millions of which are carrying out research before confirming their travel plans. Visitors to TripAdvisor can access and analyze consumer reviews of thousands of hotels, attractions and historical sites, cities and restaurants, supported by travel photos, prior to making an online reservation (Law, 2006; Milano et al., 2011; Vásquez, 2011). The TripAdvisor strategy involves the collection, analysis, exchange and use of information among tourism stakeholders, with its main purpose being to create competitiveness and technological infrastructure of supply and demand based on tourism industry, to 
increase its functionality, to create common benefits and to provide value in innovative ways (Sigala, 2012).

More than $80 \%$ of today's travelers make use of such blog sites as TripAdvisor that provide reviews and evaluations of businesses operating in the tourism sector, offering customers potential alternatives, and selection of selections, along with after-service experiences. Statistics show that $77.9 \%$ of customers who turn to online travel blog sites in search of information based on their individual preferences are influenced by the reviews of other consumers, and they take these reviews into account when making purchasing decisions (Briggs et al., 2007; Mazzarol et al., 2007; Gretzel \& Yoo, 2008; Sweeney et al., 2008; Dickinger, 2011; Molinillo et al., 2016).

This situation has created a sense that positive or negative comments can both have significant implications for the tourism sector in literature, that consumers change their minds and that online consumer behavior has been shaped from the very outset, as has been widely evaluated by many authors in connection with digital channels (Law, 2006; Briggs et al., 2007; Chung \& Buhalis, 2008; Jeong \& Jeon, 2008; Miguéns et al., 2008; O'Connor, 2008; 2010; Yoo \& Gretzel, 2009; Barcala et al., 2009; Law et al., 2009; Sparks \& Browning, 2010; Stringam et al., 2010; Lu \& Stepchenkova, 2012; Simms, 2012). Given the rapid evolution of technologies, the increasing global competition, the ever-changing consumer demands and trends, and the long-term sustainability and competitiveness fostered by advanced blog sites such as TripAdvisor are progressively dependent on a business's ability to continuously update and enrich its services and functionality. Accordingly, TripAdvisor should make progress such as producing new values, researching advanced potential sources and creating value-added production. In addition, it should internationalize its social media capabilities, its technological use of mobile facilities and the services it provides, while also expanding and enriching production capabilities with the help of travel content. TripAdvisor' leading position among blog sites operating in the tourism sector has been bolstered by its ability to allow its users and potential customers to be influential in terms of the opinions and comments made (Gretzel \& Yoo, 2008; Dahlander \& Gann, 2010).

The change brought to online consumer behaviors through contentrich social networking sites has led to changes in some of the criteria related to hotel preferences in TripAdvisor. Even the simplest form of criteria, being positive or negative opinions and comments about hotels, 
can have an impact on consumer behavior (Anderson, 2012; Yang \& Chao, 2015; Chen \& Law, 2016; Chen \& Ng, 2017; Lombardi \& Vernero, 2017; Tsao et al., 2018). An analysis of studies investigating this effect reveals that positive or negative opinions and comments influence consumer behaviors. Some potential customers, before making hotel preferences, review the observations made on TripAdvisor, and show that they are oriented towards hotel preferences with positive feedback and higher rating scores, indicating that online consumer behaviors are shaped in this direction (Park \& Allen, 2013; Liu \& Park, 2015; Luo et al., 2015; Molinillo et al., 2016; Chan et al., 2017; Phillips et al., 2017; Mariani \& Borghi, 2018; Ruiz-Mafe et al., 2018). It is seen that, unlike the other study results detected, some potential customers find negative opinions and reviews of hotels to be more realistic, and this shapes their online consumer behaviors in this direction (Godes \& Mayzlin, 2004; Casaló et al., 2015; Park \& Nicolau, 2015).

Many studies have been carried out to determine which criteria derived from the comments and reviews made on TripAdvisor, which is accepted as the leading blog site in the tourism sector, are important factors in determining purchasing behaviors in terms of their effect on consumer preferences. The opinions and comments about hotels that are effective in consumer preferences play a decisive role in purchasing behaviors (Jeong \& Jeon, 2008; Barcala et al., 2009), among which staffservice, location-transport access and price-performance (Barriocanal et al., 2010); architectural structure, food and beverage and priceperformance (O'Connor, 2010); architectural structure, staff-service, food and beverage, and price-performance (Stringam et al., 2010); architectural structure, cleanliness, staff-service, food-beverage and location-transport access (Bronner \& Hoog, 2011); staff-service (Tejada \& Moreno, 2013); architectural structure (Lado-Sestayo et al., 2014; Zhou et al., 2014); location-transport access (Limberger et al., 2014); architectural structure, cleanliness, staff-service, location-transportation and price-performance (Xie et al., 2014); cleanliness and location-transport access (Xie et al., 2016); staff-service and architectural structure (Molinillo et al., 2016) are the most influential.

It is apparent that the entertainment-animation criterion is ignored in the studies conducted in literature in which city hotels are examined and evaluated (Jeong \& Jeon, 2008; Barcala et al., 2009; Barriocanal et al., 2010; O'Connor, 2010; Stringam et al., 2010; Bronner \& Hoog, 2011; Tejada \& Moreno, 2013; Lado-Sestayo et al., 2014; Limberger et al., 2014; Xie et al., 2014; Zhou et al., 2014; Xie et al., 2016; Molinillo et al., 2016), and that the 
entertainment-animation criteria applies mostly to holiday hotels (Yilmaz \& Aytekin, 2018). In literature, the effect of the entertainment-animation criteria on the hotel preferences of potential customers is investigated in order to eliminate the lack of such data on city hotels.

In the light of all these findings, the present study makes an assessment of the comments posted about the hotels on TripAdvisor, and determines the impact of the criteria identified in the comments and the star rating given to the hotels.

\section{EMPIRICAL MODELS, METHODS AND DATA}

At this juncture, an empirical model is determined, and the reasons for choosing the hotels in Istanbul, which straddles Asia and Europe and can be considered as Turkey's most important city in terms of its history, metropolitan structure and tourism mobility, are examined. Considering the literature review, the obtained theoretical information and the applied content analysis, the model explains in detail the impact of seven independent variables - which are accepted as important by guests considering the online comments by TripAdvisor users - on the star ratings given to hotels. In addition, the data sets related to the variables included in the model, the forms of these data sets and the panel data method that will be utilized in the empirical analysis are clarified.

The first criterion is hotel architecture, and relates to the hotel architecture and the general situation of the hotel, the size of the rooms, the usefulness of the rooms, the usability and uniqueness of the properties and the hotel fixtures and rooms, the swimming areas (sea, pool, aqua park, beach, etc.), the common areas (restaurants, bars, spa, sauna, Turkish Bath, amphitheater, gym, mini club, etc.), and the accessibility of all points within the hotel. The second criterion relates to cleanliness, and includes such sub-headings as general hotel cleanliness, room cleanliness (bath, toilet, bed linen, etc.), the cleanliness of the environment and the swimming areas (sea, pool, aqua park-beach, etc.), the cleanliness of the common areas (restaurants, bars, spa, sauna, Turkish Bath, amphitheater, mini club etc.), and the cleanliness of the equipment throughout the hotel. The third criterion relates to food and beverage, and includes variety, flavor, freshness, brand quality, quality of service, the accessibility of the food and beverage areas, children's restaurants and menus, and the variety and quality of the hotel bars and the minibars. The fourth criterion relates to staff-service, and comprises such sub-topics as staff interest and 
professionalism, service speed and quality, problem solving, friendliness and kindness, check-in/check-out, room service and lobby services, welcome and farewell, and bell boy services. The fifth criterion relates to entertainment-animation, and covers the entertainment provided (parties, concerts, DJ performances, live music, etc.), animation (sea, pool, aqua park, beach, etc.), mini clubs (kids' activities and child care), spa, sauna, Turkish Bath, amphitheater, sporting activities (paragliding, balloon, jet ski, games, competitions, etc.), and local tours and excursions. The sixth criterion relates to location and transport access, and covers the proximity of the hotel to other locations (airport, bus station, hospital, shopping centers, amusement centers, etc.); the frequency of transport services around the region; the proximity of the hotel to the region's unique and historical sites; the public transport system in the city; and the proximity of the accommodation units to the swimming areas, common areas and restaurants in the hotel. The recommendation criterion, which is the final criterion within the specified criteria, includes such subheadings as positive or negative recommendations, as well as the satisfaction with price/performance.

\section{Empirical Model}

To investigate the impact on the hotel star rating of the criteria prioritized by customers in their analysis of the available hotel options, the following empirical model panel is developed in this study;

$$
\begin{aligned}
& \ln S P_{i t}=\beta_{0}+\beta_{1} \ln A R C_{i t}+\beta_{2} \ln G C_{i t}+\beta_{3} \ln F B_{i t}+\beta_{4} \ln P S_{i t}+\beta_{5} \ln E A_{i t}+ \\
& \beta_{6} \ln L O C_{i t}+\beta_{7} \ln R E C_{i t}+\varepsilon_{i t}
\end{aligned}
$$

in which the InSP refers to the average star rating of the hotel; $\ln A R C$ to the architectural structure of the hotel; $\ln G C$ to the hotel's general cleaning services; $\ln F B$ to food and beverage quality within the hotel concept; $\ln P S$ to the staff and service quality of the hotel; $\ln E A$ to the entertainment \& animation services provided by the hotel; $\ln L O C$ to the hotel's location; and $\ln R E C$ to the recommendations made by other consumers. Furthermore, $i, t$ and $\varepsilon_{i t}$ refer respectively to the horizontal section (hotel), period of time and disturbance terms. 


\section{Data}

The hotels located in Istanbul listed on TripAdvisor were examined, and the 25 hotels that received the most reviews and comments on the website are included in the study sample. While generating data sets, the comments and star points given to each hotel were included, along with their monthly average in the model, and " $2015 \mathrm{~m}-12018 \mathrm{~m} 12$ " observation interval was evaluated. The number of related comments and hotels specified in the data set are explained in detail in Annex A.

Some 12,000 comments made about the 25 hotels selected for the study were examined and subjected to a content analysis, resulting in seven different criteria with different subheadings being determined in connection with the literature reviews. These criteria include the main headings of hotel architecture, cleanliness, food-beverage, staff-service, entertainment-animation, location and advice.

\section{Statistical Analysis}

LLC and IPS unit tests were carried out for the subject of the study, and the stability of the data included in the study was tested. In the following stage, preliminary tests were made of the proposed panel regression analysis model, after which coefficient estimation analyses were carried out to determine the weighting of the determined criteria.

\section{LLC Unit Root Testing}

The LLC unit root test revealed that individual unit root tests have only limited power against the alternative hypothesis, and that dramatically permanent deviations from the balance will occur (Levin et al., 2002). Accordingly, the zero hypothesis of this research can be concluded to comprise the unit root for each separate time series, while alternative hypothesis is static for each time series. In the light of these findings, the basic equation of the test was developed as follows;

$\Delta y_{i t}=\delta y_{i t-1}+\sum_{L=1}^{p_{i}} \theta_{i L} \Delta y_{i t-L}+\propto_{m i} d_{m t}+\varepsilon_{i t}, \quad m=1,2,3$.

in which $d_{m t}$ refers to the deterministic variable and $\propto_{m i}$ to the coefficient vector. Since the $P_{i}$ value in the equation is unidentified, a three-phase procedure is applied for the test-related calculations. In the first stage, an 
Augmented Dickey Fuller (ADF) regression is made separately for each series included in the panel, after which, estimations are made of the longterm and short-term standard error rates for each series, while a measurement of the pooled $t$ statistic is made for the final step.

In first phase, the above stated hypothesis is applied for each horizontal section. The lag length $\left(p_{i}\right)$ is allowed to be different among the horizontal sections. The maximum lag length $\left(p_{\max }\right)$ is chosen for the period $\mathrm{T}$, and the $\mathrm{t}$ statistic of $\theta_{i L}$ is preferred if a smaller delay length is selected. According to the null hypothesis, it is observed that $t$ statistics have a standard regular distribution.

After $P_{i}$ is calculated, $\Delta y_{i t}$ and $y_{i t-1}$ regressions are applied to the appropriate deterministic variable $\Delta y_{i t-L}$ and $d_{m t}$, and the inclusions $e_{i t}$ and $v_{i t-1}$ are obtained. These inclusions are normalized through the following calculations: $e_{i t}=\frac{\sigma_{i t}}{\sigma_{\varepsilon i}}$ and $v_{i t-1}=\frac{v_{i t}-1}{\sigma_{\varepsilon i}}$. In the second phase, calculations are made of the long- and short-term standard error rates. Referring to the null hypothesis accepting the unit root's existence, the model's long-term variance is measured through the following calculation (Levin et al., 2002):

$\sigma_{y i}^{2}=\frac{1}{T-1} \sum_{t=2}^{T} \Delta y_{i t}^{2}+2 \sum_{L=1}^{K} w_{K L}\left[\frac{1}{T-1} \sum_{t=2+L}^{T} \Delta y_{i t} \Delta y_{i t-L}\right]$

in which $K$ refers to the transition lag, and $L$ is the regular lag. $K$ should be measured in such a way that the consistency of the variance is not disturbed. The $w_{K L}=1-\left(\frac{L}{K+1}\right)$ formula is used to calculate the Bartlett kernel, and the following formula is used to calculate the mean standard error;

$S_{N}=\frac{1}{N} \sum_{i=1}^{N} s_{i}$

Panel test statistics are calculated in the third phase using the following regression with the number of NT observations;

$e_{i t}=\rho v_{i, t-1}+\varepsilon_{i t}$

in which, $t$ refers to mean number of observations per horizontal section, and $\rho$ refers to the mean lag length of each ADF (Çetin \& Ecevit, 2010). 


\section{IPS Unit Root Testing}

Based on the results of this test, calculated with the average of particular unit root test statistics and allowing for heterogeneity of the horizontal sections, the following regression equation can be developed (Baltagi, 2011; Im et al., 2003);

$\Delta y_{i t}=\mu_{i}+\beta_{i} y_{i, t-1}+\sum_{k=1}^{p_{i}} \theta_{i, k} \Delta y_{i, t-k}+\gamma_{i} t+\varepsilon_{i t}$

The equation has a constant and trendy structure, and so the trend should be deleted from the equation to obtain a constant equation. The rejection of null hypothesis according to the IPS test implies that one or more than one of the series is static.

Im et al. (2003) measured the $t$ statistics of each horizontal section as $t_{i}=\beta_{i} / \operatorname{sh}\left(\beta_{i}\right)$, and then calculated the mean $\mathrm{Z}$ of $t_{i}$ using the following formula;

$Z=\left(\frac{\sqrt{N}(t-E(t)}{\operatorname{var}(t)}\right) \sim N(0,1)$

The $t$ value can be calculated using the following formula (Çetin \& Ecevit, 2010);

$t=\frac{1}{N}\left(\sum_{i=1}^{N} t_{i}\right)$

\section{RESULTS}

At this stage of the study, the results of the empirical analysis aimed at determining the data levels of the 25 hotels in Istanbul and the factors affecting the hotel preferences of the customers are investigated. To this end, the stability of the series is first examined via a panel unit root test, and the required preliminary tests for the selection of either the panel constant or the panel random effects models are made. Finally, the coefficients of the effects of each independent variable on hotel preferences are calculated. 


\section{Unit Root Test Results}

The unit root tests developed by Levin et al. (2002) and Im et al. (2003) are applied to the Istanbul data, and the stability of the series is calculated within the model. The unit root test results are presented in Table 1.

Table 1. Unit Root Test Results for Istanbul

\begin{tabular}{lcc}
\hline Variable & LLC & IPS \\
\hline \multirow{2}{*}{$\ln S P$} & $-4.813^{*}$ & $-10.989^{*}$ \\
& $(0.000)$ & $(0.000)$ \\
$\ln A R C$ & $-4.475^{*}$ & $-10.074^{*}$ \\
& $(0.000)$ & $(0.000)$ \\
$\ln G C$ & $-3.124^{*}$ & $-8.550^{*}$ \\
$\ln F B$ & $(0.000)$ & $(0.000)$ \\
& $-3.800^{*}$ & $-8.199^{*}$ \\
$\ln P S$ & $(0.000)$ & $(0.000)$ \\
& $-3.871^{*}$ & $-11.469^{*}$ \\
$\ln E A$ & $(0.000)$ & $(0.000)$ \\
$\ln L O C$ & $-3.476^{*}$ & $-7.638^{*}$ \\
$\ln R E C$ & $(0.000)$ & $(0.000)$ \\
& $-6.193^{*}$ & $-10.941^{*}$ \\
& $(0.000)$ & $(0.000)$ \\
& $-4.659^{*}$ & $-9.440^{*}$ \\
& $(0.000)$ & $(0.000)$ \\
\hline
\end{tabular}

${ }^{*} \mathrm{p}<0.001$.

In the application of unit root tests, the Newey-West estimator is preferred to address the autocorrelation problem, while the optimum delay lengths are determined based on the Schwarz Information Criteria (SIC). An examination of the results presented in Table 1 reveals that the null hypothesis, which claims that the series contains a root unit for all variables, is rejected by both tests, and that the variables are static at all level values. As this finding contradicts the situation necessary for the identification of a co-integration relationship between variables, the coefficient estimation leads to the use of the panel regression method, based on the level values of the series. From this it can be concluded that the comments made on TripAdvisor are not influenced by each other, and that the data can be static. 


\section{Preliminary Test Results}

When deciding whether to apply fixed or random effects in the panel data analysis, it is necessary to test the pooled regression of the model prior to the estimation of the coefficient, and to carry out preliminary tests. Before proceeding with the application of preliminary tests, it is necessary to determine whether to use fixed effects or pooled regression. An F-test was applied for this purpose, and from the results it was concluded that the null hypothesis determining the pooled regression should be used is rejected, and that the fixed effects model should be preferred. The results of the F-test are presented in Table 2.

Table 2. F-test Results

\begin{tabular}{lccc}
\hline & Statistic & d.f. & Prob. \\
\hline Cross-section F & 2.132 & $(24,868)$ & 0.001 \\
Cross-section Chi-square & 51.569 & 24 & 0.000 \\
\hline
\end{tabular}

After determining that the fixed effects model should be preferred over a pooled regression model, LM tests were applied to choose between the random effects and pooled regression models. The results of the different LM tests, which indicate that the zero hypotheses and pooled models should be preferred over the random effects model, are presented in Table 3. It can be seen from the result that the null hypothesis is rejected for all tests, meaning that the random effects model should be selected over the pooled model.

Table 3. LM Test Results

\begin{tabular}{lccc}
\hline Tests & $\begin{array}{c}\text { Cross- } \\
\text { section }\end{array}$ & Time & Both \\
\hline Breusch-Pagan & 4.355 & 0.075 & 4.431 \\
& $(0.036)$ & $(0.783)$ & $(0.035)$ \\
Honda & 2.087 & -0.274 & 1.281 \\
& $(0.018)$ & -- & $(0.100)$ \\
King-Wu & 2.087 & -0.274 & 1.432 \\
& $(0.018)$ & -- & $(0.076)$ \\
Standardized Honda & 3.796 & -0.181 & -3.846 \\
& $(0.000)$ & -- & -- \\
Standardized King-Wu & 3.796 & -0.181 & -3.588 \\
& $(0.000)$ & -- & -- \\
Gourierioux et al. & -- & -- & 4.355 \\
& & & $(<0.05)$ \\
\hline
\end{tabular}


Finally, the results of the Hausman test, which is used to choose between the fixed effects and random effects models, indicate that the null hypothesis that implies the necessity to use the random effects model, is rejected, and that the constant effects model is the most accurate model for the analysis. The results of the Hausman Test are presented in Table 4.

Table 4. Hausman Test Results

\begin{tabular}{lccc}
\hline & Chi-Sq. Statistic & Chi-Sq. d.f. & Prob. \\
\hline Cross-section random & 10.699 & 7 & 0.152 \\
\hline
\end{tabular}

\section{Coefficient Estimation Results}

The results of the coefficient estimation of the panel constant effects for the interpretation of the determined factors and the determination of severity levels are presented in detail in Table 5.

Table 5. Panel Fixed Effects Coefficient Estimation Results

\begin{tabular}{|c|c|c|c|c|}
\hline Variable & Coefficient & Std. Error & t-Statistic & Prob. \\
\hline $\ln A R C$ & 0.158 & 0.005 & 29.395 & 0.000 \\
\hline $\ln G C$ & 0.167 & 0.007 & 22.566 & 0.000 \\
\hline InFB & 0.170 & 0.005 & 29.214 & 0.000 \\
\hline $\operatorname{lnPS}$ & 0.154 & 0.003 & 39.560 & 0.000 \\
\hline $\operatorname{lnEA}$ & 0.000 & 0.001 & 0.479 & 0.631 \\
\hline $\operatorname{lnLOC}$ & 0.163 & 0.010 & 15.324 & 0.000 \\
\hline $\ln R E C$ & 0.171 & 0.016 & 10.586 & 0.000 \\
\hline $\mathrm{C}$ & 0.024 & 0.014 & 1.652 & 0.098 \\
\hline \multicolumn{5}{|c|}{ Cross-section fixed (dummy variables) } \\
\hline Effects Specification & & & S.D. & Rho \\
\hline Cross-section random & & & 0.001 & 0.036 \\
\hline Idiosyncratic random & & & 0.007 & 0.963 \\
\hline \multicolumn{5}{|l|}{ Weighted Statistics } \\
\hline R-squared & 0.930 & \multicolumn{2}{|c|}{ Mean dependent var } & 0.960 \\
\hline Adjusted R-squared & 0.929 & \multicolumn{2}{|c|}{ S.D. dependent var } & 0.028 \\
\hline S.E. of regression & 0.007 & \multicolumn{2}{|c|}{ Sum squared resid } & 0.050 \\
\hline F-statistic & 1707.138 & \multicolumn{2}{|c|}{ Durbin-Watson stat } & 2.179 \\
\hline Prob(F-statistic) & 0.000 & & & \\
\hline \multicolumn{5}{|l|}{ Unweighted Statistics } \\
\hline R-squared & 0.965 & \multicolumn{2}{|c|}{ Mean dependent var } & 1.471 \\
\hline Sum squared resid & 0.051 & \multicolumn{2}{|c|}{ Durbin-Watson stat } & 2.122 \\
\hline
\end{tabular}


According to the data in Table 5, when the results of the fixed effects model for Istanbul are examined, it is seen that the effects of the other observed factors on the star rating averages of hotels are positive and statistically significant.

It can be understood from the findings that hotel architecture increases the guest preference and average star rating by $0.15 \%$; the cleanliness of the hotel by $0.16 \%$; the food and beverage facilities by $0.17 \%$; the staff-service quality by $0.15 \%$; the hotel's location and transport access by $0.16 \%$; and finally, the recommendations made about the hotel by $0.17 \%$. The entertainment-animation criterion was found to have no statistically significant effect on guest preference or the average star rating.

\section{DISCUSSION AND CONCLUSIONS}

An evaluation of the findings reveals that all criteria other than entertainment-animation programs have the power to influence the same proportion of potential hotel guests in Istanbul. Among these criteria, it is concluded that those such as recommendations from other customers, the food-beverage concept, cleanliness, location and transportation, architectural structure and the quality of staff-services are close to each other in terms of their influence over potential customers. In addition, it can be understood that the entertainment-animation criterion for Istanbul is not important for potential customers and does not affect choice.

Considering the criteria garnered through a content analysis of the comments posted on the TripAdvisor.com.tr website, the fact that recommendations are the leading factor affecting hotel choice in Istanbul, that most of the hotels in the rankings are four-star boutique-style hotels and resort district in contrast to the five-star hotels in Turkey, and that most of the hotels are located on the European side of the city and very close to each other indicates that these hotels have similar concepts and facilities. This indicates that the criteria determined by potential customers are effective, and that they may be influenced by recommendations or non-recommendations, as included in the aforementioned criteria. It is apparent also that "price-performance" satisfaction, which falls below the recommendation effect in previous literature, is also taken into consideration by potential customers in Istanbul, concurring with the results of previous literature (Jeong \& Jeon, 2008; Barcala et al., 2009; Barriocanal et al., 2010; O'Connor, 2010; Limberger et al., 2014). In general, a city hotel's location and transportation facilities are more important for 
customers, along with such criteria as proximity to destination, foodbeverage and staff-service facilities; and the impact of recommendation and satisfaction with price/performance are much more important considering the capacity to take measures against price differences and the characteristics of the hotels in terms of preference for those who are more prominent than their counterparts.

The fact that the food and beverage criterion comes to the fore among other factors indicates the prevalence of a "bed-breakfast" concept, and that the breakfast services offered to the guests by the hotel is of high importance, despite being free of charge, and is evaluated in terms of quality, taste, variety and presentation. Furthermore, the quality, taste, variety and presentation of the food and beverages offered at other meals are considered as another important factor by the customers. In this area, customers tend to look at the variety of food and beverage options, the bars in the hotel concept and mini bars in the rooms, the freshness of the products used, the quality of the products, the taste, presentation quality and service times, as well as the availability of popular brands. Compared to other hotels in the holiday regions, the concept of food and beverage is more important in this region, even though the concept differences are limited in Istanbul when compared to other regions in Turkey. These results concur with those of the previous studies by Barriocanal et al. (2010), O'Connor (2010) and Stringam et al. (2010).

The importance attributed to cleanliness in the present study stands out among the other criteria, and parallels the results of previous studies in literature (Stringam et al., 2010; Limberger et al., 2014; Xie et al., 2014). It can be said that for the hotels in Istanbul, as is the case in Turkey as a whole, the general cleanliness of the hotel and the rooms; the cleanliness of the facilities and equipment in both the common and private areas; the environmental and landscape cleanliness; the cleanliness of the swimming areas, such as indoor and outdoor pools; and the cleanliness of social areas such as restaurants, bars, spas, Turkish Bath and sauna are important for both customers and potential customers, are naturally an issue of primary importance.

Istanbul holds an important place in the holiday preferences of tourists due to its historical background, its location straddling Europe and Asia, its geographical beauty, its wide variety of shopping opportunities and its unique night entertainment. As a large part of the hotels in this region are close to each other and located mainly on the European side of the city, it is possible to think that the hotel location 
criteria is one of the main criteria in hotel selection, based on the comments posted on TripAdvisor. This may also be due to the fact that most tourists want to be based close to the historical, geographical, social and shopping areas, and so hotels in locations close to such attractions cause this criterion to come to the fore. In addition, considering the distress of transportation sources of some regions, distance from transportation points of hotels, and transportation problems due to the frequency of transportation, it can be concluded that transportation in Istanbul is important for hotels in terms of their proximity to airports, bus terminals, hospitals, shopping centers, entertainment venues and transportation hubs. It can also be concluded that urban transportation facilities, such as the metro, tram, bus, minibus, Marmaray, taxi stops and sea transportation vehicles can be an important criteria affecting tourist preferences. The importance of a hotel's location and its proximity to transportation hubs brings this criterion to the fore in the comments made, paralleling the findings of studies conducted previously by Jeong \& Jeon (2008), Barcala et al. (2009), Stringam et al. (2010), Limberger et al. (2014), Xie et al. (2014) and Lado-Sestayo et al. (2014).

Hotel architecture retains a high position on the list of the criteria affecting the choices of customers and potential customers may indicate that customers believe that the four-star and boutique-style hotels in the region may pay more attention to detail and to be of greater value than five-star hotels. The availability of indoor and outdoor swimming pools, the size and usefulness of the rooms, the newness of the fixtures and fittings, the hotel common areas, Internet access and hotel parking are all important factors for customers, and are of equal importance to the other criteria. In addition, the proximity of the hotel to the city center and the sound-proofing of the hotel rooms can be considered other important factors related to the architecture of the hotels in Istanbul. Concurring with the findings of the studies by Barriocanal et al. (2010), Stringam et al. (2010), O'Connor (2010), Tejada \& Moreno (2013), Limberger et al. (2014), Zhou et al. (2014) and Molinillo et al. (2016), it can be concluded from the present study that hotel architecture is also of primary importance in this region.

The importance of the personnel-service factor is based on the desire of customers to be provided with a fully professional service by professional staff, in addition to the attention they expect from hotels offering four or five-star or boutique-style services in Istanbul. Because the location and transportation facilities of the hotels being over certain standards, the manner of presentation of the services, the quality and 
speed at which they are provided, the cheerfulness and friendliness of the staff, the politeness and respect received, and the way problems are resolved can be considered as being of significant importance in the eyes of the customer. Also deemed to play an important role in this regard are the means of check-in/check-out, room series, the lobby and reception, bell boy availability, send-off, and access to a doctor or other health services. Finally, it is generally possible in hotels to use foreign language effectively for foreign-oriented tourist portfolio and to help tourists in their daily programs, to offer them alternatives, to provide them with the necessary transport and to suggest different places to eat, which increases the significance of this criterion dramatically. The significant importance attributed to the staff and service criteria in the studies of Jeong \& Jeon (2008), Barcala et al. (2009), O'Connor (2010), Stringam et al. (2010), Bronner \& Hoog (2011), Limberger et al. (2014) and Xie et al. (2016) are similar to the results obtained in the present study.

Considering the criteria determined from the comments posted on TripAdvisor, the entertainment-animation criterion in Istanbul has little impact on customers, as the hotels are planned in four or five stars and boutique styles; the facilities are limited; events such as parties, concerts, DJ performances and live music are not planned; services such as spa, sauna and Turkish Baths are not at the desired level or they are not available at all; tours, excursions and events in the region are not available and hotel architectures are not suitable for amenities such as gyms. And considering all these facts, it can be concluded that these criteria are of no importance in the preference by the customers. As hotel guests spend most of their time visiting historical and geographical sites in the city, shopping and experiencing the nightlife, it can be concluded that hotel managers in Istanbul attribute little importance to the entertainmentanimation criteria, as their guests do not spend much time in the hotel. It is thought that the absence of this criterion from previous studies may be due to studies conducted in city hotels and hostel-style accommodation and limited hotel facilities selected such as Jeong \& Jeon (2008), Barcala et al. (2009), Barriocanal et al. (2010), O'Connor (2010), Stringam et al. (2010), Bronner \& Hoog (2011), Tejada \& Moreno (2013), Zhou et al. (2014) LadoSestayo et al. (2014), Limberger et al. (2014), Xie et al. (2014, 2016), and Molinillo et al. (2016). In this respect, although the inclusion of entertainment-animation criterion in this study proves to lack significance for the hotels in Istanbul, it can be considered of great importance in the "all inclusive" and "ultra all inclusive" hotels that are predominant in 
Turkey's holiday regions (Yilmaz \& Aytekin, 2018), and this study can thus be considered to contribute to previous literature.

As can be understood from the results of the present study, it would be beneficial for hotel managers and business owners in the sector to recognize the power of social networking sites which are led by blogs. It is becoming more and more important to review the feedback of previous hotel and facility guests, to realize that even the smallest detail is shared on TripAdvisor by previous customers, and to understand that such blogs direct the buying behaviors of both current and potential customers. The opinions and comments shared by existing customers are of great importance to potential customers in the identification and evaluation of alternatives, and consequently, can serve as a guiding light for businesses in determining the aspects of their enterprises that are missing or that need improvement. Businesses can ensure customer satisfaction by giving priority to these points as a priority, as well as optimizing the weaknesses detected by such criteria through taking correct steps to gain the potential customers.

It can be understood from the present study that hotels with criteria with high coefficients have a good working understanding of, and are considered successful in terms of tourist preferences. It is suggested that they should continue their service understanding with the strategies adopted. In addition, hotels with positive yet low coefficients should work towards paying attention to the criteria with low coefficients, as this may aid in their efforts to attract more tourists.

For Istanbul, based on the comments made on the TripAdvisor website, it is seen that almost all of the criteria identified through the content analysis have the same effect on potential customers when identifying their alternatives on making choices. Among these criteria, recommendations by previous customers, the food-beverage concept, the cleanliness factor, hotel location and transportation, the architectural structure of the hotel and quality of staff-service have equal levels of importance for potential customers, and furthermore, the absence of entertainment-animation programs, or such programs not being at the desired level in hotels, can be considered a shortcoming. Accordingly, hotel managers or facility administrators may consider expanding the scope of the services provided in this regard, although not at a level to match the complex structure of Turkey's holiday regions, and to organize such events as parties, concerts, DJ performances and live music shows, providing or elevating such services as spas, saunas and Turkish Baths to 
the desired levels, or to provide such services if they are lacking; organizing suitable tours, excursions and trips; and of changing the hotel architectures in such a way that facilities such as gyms can be accommodated. In this way, managers and administrators can increase the level of satisfaction of their guests in the facilities by considering that such elements are important as a guiding factor in identifying and evaluating alternatives to potential customers.

The 25 selected hotels all need to pay attention to the entertainment and animation criteria, which is clearly lacking. The fact that entertainment and animation criterion has in the past been overlooked in most previous researches of city hotels leads to the conclusion that this criterion is the most important factor. Entertainment and animation might not be a determining factor among tourists in their selection of a city hotel, yet organizing such activities in recognition of the cultural and historical features of the city will provide great benefits to the hotels. For example, offering a service giving priority to hotel guests for entry to historical and cultural sites such as Topkapi Sarayi, Dolmabahce Sarayi, Galata Kulesi etc. will have a very positive effect on tourist preferences. Also, planning Bosphorus Tours, guided city tours and providing special vehicles for tourists to take them shopping, dining and for other evening entertainment as part of the entertainment and animation activities provided by the hotel will further aid hotels in attracting tourists.

In this study, a four-year (2015-2018) data set for Istanbul was obtained from TripAdvisor. Considering that the necessity of extending the data set interval could be interpreted as a limitation, the data range was expanded, and the previous years' comments were examined prior to the analysis phase of the study. When the year range is extended based on the data set, the number of comments is insufficient and the contents are incomplete. For these reasons, it was impossible to reach the content of the seven criteria based on four years of data over the limited and inadequate comments.

In addition, assuming that the comments in the extended data set are sufficient in number and full in content, it is foreseen that there may be increases or decreases in the coefficients that determine the importance of the variables, as well as changes in the significance level of the entertainment and animation criteria that lack significance for Istanbul.

It can also be said that the sufficient number of comments and the full coverage of the criteria selected for analysis in this study supported the selection of these 25 Istanbul hotels, aside from their garnering of the 
highest number of reviews on TripAdvisor. This number can be deemed sufficient, as the luxury level, size, facilities and locational advantages of the first 25 hotels, which were selected based on the number of reviews, enabled the development of the seven criteria as a content.

\section{REFERENCES}

Anderson, C. K. (2012). The Impact of Social Media on Lodging Performance. Cornell Hospitality Report, 12(15), 6-11.

Baird, C. H., \& Parasnis, G. (2011). From social media to social customer relationship management. Strategy \& Leadership, 39(5), 30-37.

Baltagi, B. (2011). Useful introduction and solid training in Econometrics. Berlin: Springer.

Barcala, M. F., Díaz, M. G., \& Rodriguez, J. P. (2009). Factors influencing guests' hotel quality appraisals. European Journal of Tourism Research, 2(1), 25-40.

Barriocanal, E. G., Sicilia, M. A., \& Korfiatis, N. (2010). Exploring hotel service quality experience indicators in user-generated content: A case using trip advisor data. Association for Information Systems, 9(1), 1-12.

Bausch, P., Haughey, M., \& Hourihan, M. (2002). We Blog: Publishing Online with Weblogs. New York, NY: John Wiley \& Sons, Inc.

Boyd, D., \& Ellison, N. B. (2007). Social Network Sites: Definition, History, and Scholarship. Journal of Computer-Mediated Communication, 13(1), 210-230.

Briggs, S., Sutherlanda, J., \& Drummond, S. (2007). Are hotels serving quality? An exploratory study of service quality in the Scottish hotel sector. Tourism Management, 28(4), 1006-1019.

Bronner, F., \& Hoog, R. d. (2011). Vacationers and eWOM: Who Posts, and Why, Where, and What? Journal of Travel Research, 50(1), 15-26.

Buhalis, D., \& Law, R. (2008). Progress in information technology and tourism management: 20 years on and 10 years after the Internet-The state of eTourism research. Tourism Management, 29(4), 609-623.

Casaló, L. V., Flavián, C., Guinalíu, M., \& Ekinci, Y. (2015). Avoiding the dark side of positive online consumer reviews: Enhancing reviews' usefulness for high riskaverse travelers. Journal of Business Research, 68(9), 1829-1835.

Chan, I. C., Lam, L. W., Chow, C. W., Fong, L. H., \& Law, R. (2017). The effect of online reviews on hotel booking intention: The role of reader-reviewer similarity. International Journal of Hospitality Management, 66(1), 54-65.

Chen, G. M., \& Ng, Y. M. (2017). Nasty online comments anger you more than me, but nice ones make me as happy as you. Computers in Human Behavior, 71(1), 181-188.

Chen, Y.-F., \& Law, R. (2016). A Review of Research on Electronic Word-of-Mouth in Hospitality and Tourism Management. International Journal of Hospitality and Tourism Administration, 17(4), 347-372.

Chung, J. Y., \& Buhalis, D. (2008). Web 2.0: A study of online travel community. Information and Communication Technologies in Tourism, 1(1), 70-81.

Constantinides, E., \& Stagno, M. C. (2011). Potential of the social media as instruments of higher education marketing: a segmentation study. Journal of Marketing for Higher Education, 21(1), 7-24. 
Çetin, M., \& Ecevit, E. (2010). Sağlık Harcamalarının Ekonomik Büyüme Üzerindeki Etkisi: OECD Ülkeleri Üzerine Bir Panel Regresyon Analizi. Doğuş Üniversitesi Dergisi, 11(2), 166-182.

Dahlander, L., \& Gann, D. M. (2010). How open is innovation? Research Policy, 39(6), 699709.

Deng, S., Huang, L., \& Xu, G. (2014). Social network-based service recommendation with trust enhancement. Expert Systems with Applications, 41(18), 8075-8084.

Dickinger, A. (2011). The Trustworthiness of Online Channels for Experience - and Goal Directed Search Tasks. Journal of Travel Research, 50(4), 378-391.

Eley, B., \& Tilley, S. (2009). Online Marketing Inside Out (Online Marketing: Sitepoint). Canada: SitePoint Pty.Ltd.

Godes, D., \& Mayzlin, D. (2004). Using Online Conversations to Study Word-of-Mouth Communication. Marketing Science, 23(4), 545-560.

Gretzel, U., \& Yoo, K. H. (2008). Use and Impact of Online travel Reviews. Information and Communication Technologies in Tourism, 1(1), 35-46.

Hashim, N. H., \& Murphy, J. (2007). Branding on the web: Evolving domain name usage among Malaysian hotels. Tourism Management, 28(2), 621-624.

Howe, J. (2009). Crowdsourcing: Why the Power of the Crowd Is Driving the Future of Business. New York City: Crown Business.

Im, K. S., Pesaran, M., \& Shin, Y. (2003). Testing for Unit Roots in Heterogeneous. Journal of Econometrics, 115(1), 53-74.

Jeong, M., \& Jeon, M. M. (2008). Customer Reviews of Hotel Experiences through Consumer Generated Media (CGM). Journal of Hospitality \& Leisure Marketing, 17(1), 121-138.

Ladhari, R., \& Michaud, M. (2015). eWOM effects on hotel booking intentions, attitudes, trust,and website perceptions. International Journal of Hospitality Management, $46(3), 36-45$.

Lado-Sestayo, R., Otero-González, L., \& Vivel-Búa, M. (2014). Impact of the location and market structure in the performance of hotel establishments. Tourism $\mathcal{E}$ Management Studies, 10(2), 41-49.

Law, R. (2006). Internet and tourism. Part XXI. TripAdvisor. Journal of Travel \& Tourism Marketing, 20(1), 75-77.

Law, R., Leung, R., \& Buhalis, D. (2009). Information Technology Applications in Hospitality and Tourism: A Review of. Journal of Travel \& Tourism Marketing, 26(5), 599-623.

Lee, M., \& Youn, S. (2009). Electronic word of mouth (eWOM): How eWOM platforms influence consumer product judgement. International Journal of Advertising, 28(3), 473-499.

Leung, D., Law, R., Hoof, H. V., \& Buhalis, D. (2013). Social Media in Tourism and Hospitality: A Literature Review. Journal of Travel \& Tourism Marketing, 30(1), 322.

Levin, A., Lin, C.-F., \& Chu, C.-S. J. (2002). Unit root tests in panel data: asymptotic and finite-sample properties. Journal of Econometrics, 108(1), 1-24.

Levy, S. E., Duan, W., \& Boo, S. (2013). An Analysis of One-Star Online Reviews and Responses in the Washington, D.C., Lodging Market. Cornell Hospitality Quarterly, 54(1), 49-63.

Limberger, P. F., Anjos, F. A., Meira, J. V., \& Anjos, S. J. (2014). Satisfaction in hospitality on TripAdvisor.com: An analysis of the correlation between evaluation criteria and overall satisfaction. Tourism \& Management Studies, 10(1), 59-65. 
Litvin, S. W., Goldsmith, R. E., \& Pan, B. (2008). Electronic word-of-mouth in hospitality and tourism management. Tourism Management, 29(3), 458-468.

Liu, Z., \& Park, S. (2015). What makes a useful online review? Implication for travel product websites. Tourism Management, 47(1), 140-151.

Lombardi, I., \& Vernero, F. (2017). What and who with: A social approach to doublesided recommendation. International Journal of Human-Computer Studies, 101(1), $62-75$.

Lu, W., \& Stepchenkova, S. (2012). Ecotourism experiences reported online: Classification of satisfaction attributes. Tourism Management, 33(3), 702-712.

Luo, C., Luo, X. R., Xu, Y., Warkentin, M., \& Sia, C. L. (2015). Examining the moderating role of sense of membership in online review evaluations. Information $\mathcal{E}$ Management, 52(3), 305-316.

Mariani, M. M., \& Borghi, M. (2018). Effects of the Booking.com rating system: Bringing hotel class into the picture. Tourism Management, 66(1), 47-52.

Mazzarol, T., Sweeney, J., \& Soutar, G. (2007). Conceptualizing word-of-mouth activity, triggers and conditions: an exploratory study. European Journal of Marketing, 41(11), 1475-1494.

Miguéns, J., Baggio, R. F., \& Costa, C. (2008). Social media and Tourism Destinations: TripAdvisor Case Study. Advances in Tourism Research, 194(1), 1-6.

Milano, R., Baggio, R., \& Piattelli, R. (2011). The effects of online social media on tourism websites. Information and Communication Technologies in Tourism, 1(1), 471-483.

Molinillo, S., XimĖnez-de-Sandoval, J. L., Fernández-Morales, A., \& Coca-Stefaniak, A. (2016). Hotel assessment through social media: The case of TripAdvisor. Tourism $\mathcal{E}$ Management Studies, 12(1), 15-24.

Murugesan, S. (2007). Understanding Web 2.0. Australasian Journal of Social Science, 9(4), 34-41.

Nardi, B. A., Schiano, D. J., Gumbrecht, M., \& Swartz, L. (2007). Why we blog. Communication of the ACM, 47(12), 41-46.

Neuhofer, B., Buhalis, D., \& Ladkin, A. (2012). Conceptualising technology enhanced destination experiences. Journal of Destination Marketing \& Management, 1(1), 3646.

O'Connor, P. (2008). User-Generated content and travel: A case study on Tripadvisor.Com. Information and Communication Technologies in Tourism, 1(1), 4758.

O'Connor, P. (2010). Managing a hotel's image on TripAdvisor. Journal of Hospitality Marketing \& Management, 19(7), 754-772.

Ostrander, B. (2007). Problems and Solutions to Corporate Blogging: Model Corporate Blogging Guidelines. Journal of High Technology Law, 7(1), 226-248.

Pan, B., \& Crotts, J. C. (2007). Travel Blogs and Their Implications for Destination Marketing. Journal of Travel Research, 46(1), 35-45.

Park, D.-H., \& Kim, S. (2008). The effects of consumer knowledge on message processing of electronic word-of-mouth via online consumer reviews. Electronic Commerce Research and Applications, 7(4), 399-410.

Park, S., \& Nicolau, J. L. (2015). Asymmetric effects of online consumer reviews. Annals of Tourism Research, 50(1), 67-83.

Park, S.-Y., \& Allen, J. P. (2013). Responding to online reviews: Problem solving and engagement in hotels. Cornell Hospitality Quarterly, 54(1), 64-73. 
Phillips, P., Barnes, S., Zigan, K., \& Schegg, R. (2017). Understanding the impact of online reviews on hotel performance: An empirical analysis. Journal of Travel Research, 56(2), 235-249.

Prensky, M. (2001). Digital natives, digital immigrants. On the Horizon, 9(5), 1-6.

Rosario, A. H., Rodríguez, M. G., \& Pérez, M. C. (2013). Development of social media and web 2.0 in the top hotel chains. Tourism E Management Studies, 9(1), 13-19.

Ruiz-Mafe, C., Chatzipanagiotou, K., \& Curras-Perez, R. (2018). The role of emotions and conflicting online reviews on consumers' purchase intentions. Journal of Business Research, 89(1), 36-344.

Seyrek, İ. H., \& Yilmaz, E. S. (2016). Tüketicilerin satın alma kararlarında sosyal paylaşım sitelerinin etkisi. The Journal of Academic Social Science, 37(4), 43-62.

Sigala, M. (2012). Exploiting Web 2.0 for new service development: Findings and implications from the Greek tourism industry. International Journal of Tourism Research, 14(6), 551-566.

Simms, A. (2012). Online user-generated content for travel planning - different for different kinds of trips? E-review of Tourism Research, 10(3), 76-85.

Sparks, B. A., \& Browning, V. (2010). Complaining in cyberspace: The motives and forms of hotel guests' complaints online. Journal of Hospitality Marketing $\mathcal{E}$ Management, 19(7), 797-818.

Stringam, B. B., \& Gerdes Jr, J. (2010). An analysis of word-of-mouse ratings and guest comments of online hotel distribution sites. Journal of Hospitality Marketing $\mathcal{E}$ Management, 19(7), 773-796.

Stringam, B. B., Gerdes Jr, J., \& Vanleeuwen, D. M. (2010). Assessing the importance and relationships of ratings on user-generated traveler reviews. Journal of Quality Assurance in Hospitality \& Tourism, 11(2), 73-92.

Sweeney, J., Soutar, G., \& Mazzarol, T. (2008). Factors influencing word of mouth effectiveness: Receiver perspectives. European Journal of Marketing, 42(3), 344-364.

Tejada, P., \& Lozano, M. (2013). Patterns of innovation in tourism 'Small and Mediumsize Enterprises'. The Service Industries Journal, 33(7), 749-758.

Tsao, H.-Y., Chen, M.-Y., Lin, H.-C. K., \& Ma, Y.-C. (2018). The asymmetric effect of review valence on numerical rating: A viewpoint from a sentiment analysis of users of TripAdvisor. Online Information Review, 43(2), 283-300.

Turkish Statistical Institute. (2018). Retrieved 16 July, 2019, from https://istanbul.ktb.gov.tr/Eklenti/66856,aralik-2018pdf.pdf?0.

Vásquez, C. (2011). Complaints online: The case of TripAdvisor. Journal of Pragmatics, 43(6), 1707-1717.

Werthner, H., \& Ricci, F. (2004). E-commerce and tourism. Communications of the ACM, 47(12), 101-105.

Williams, J. B., \& Jacobs, J. (2004). Exploring the use of blogs as learning spaces in the higher education sector. Australasian Journal of Educational Technology, 20(2), 232247.

Xie, K. L., Chen, C., \& Wu, S. (2016). Online consumer review factors affecting offline hotel popularity: Evidence from Tripadvisor. Journal of Travel \& Tourism Marketing, 33(2), 211-223.

Xie, K. L., Zhang, Z., \& Zhang, Z. (2014). The business value of online consumer reviews and management response to hotel performance. International Journal of Hospitality Management, 43(1), 1-12.

Yamamoto, G. T., \& Şekeroğlu, Ö. K. (2014). Sosyal Medya ve Blog. İstanbul: Kriter Yayınevi. 
Yang, H.-L., \& Chao, A. F. (2015). Sentiment analysis for Chinese reviews of movies in multi-genre based on morpheme-based features and collocations. Information Systems Frontiers, 17(6), 1335-1352.

Yilmaz, E. S. (2017). Analyzing the Effects of Comments on Social Networking Sites on Consumer Purchasing Decision Process. International Journal of Academic Research in Business and Social Sciences, 7(6), 140-162.

Yilmaz, E. S., \& Aytekin, M. (2018). The Determinants of Tourist Preferences of the Mediterranean Region in Turkey. Administrative Sciences, 8(4), 1-14.

Yoo, K.-H., \& Gretzel, U. (2009). Comparison of Deceptive and Truthful Travel Reviews. Information and Communication Technologies in Tourism, 1(1), 37-47.

Zheng, T., Youn, H., \& Kincaid, C. S. (2009). An analysis of customers' e-complaints for luxury resort properties. Journal of Hospitality Marketing E Management, 18(7), 718729.

Zhou, L., Ye, S., Pearce, P. L., \& Wu, M.-Y. (2014). Refreshing hotel satisfaction studies by reconfiguring customer review data. International Journal of Hospitality Management, 38(1), 1-10. 
Annex A. The Istanbul Hotels and Comments

\begin{tabular}{|c|c|c|c|}
\hline RANK & HOTEL NAME & REGION & $\begin{array}{l}\text { NUMBER OF } \\
\text { COMMENTS }\end{array}$ \\
\hline 1 & White House Hotel Istanbul & Sultanahmet & 4158 \\
\hline 2 & Hotel Amira Istanbul & Sultanahmet & 3716 \\
\hline 3 & Hotel Sultania & Sirkeci & 3267 \\
\hline 4 & Sirkeci Mansion & Sirkeci & 3245 \\
\hline 5 & Neorion Otel & Sirkeci & 3238 \\
\hline 6 & Hilton Istanbul Bosphorus & Beşiktaş & 3045 \\
\hline 7 & Conrad Istanbul Bosphorus & Beşiktaş & 2942 \\
\hline 8 & $\begin{array}{l}\text { Hilton Istanbul Bomonti Hotel \& } \\
\text { Conference Center }\end{array}$ & Şişli & 2608 \\
\hline 9 & Levni Hotel \& Spa & Sultanahmet & 2459 \\
\hline 10 & Hotel Sapphire & Sirkeci & 2281 \\
\hline 11 & Hotel Erboy & Sirkeci & 2279 \\
\hline 12 & Sura Hagia Sophia Hotel & Sultanahmet & 2162 \\
\hline 13 & Çıragan Palace Kempinski Istanbul & Beşiktaş & 2117 \\
\hline 14 & $\begin{array}{l}\text { DoubleTree by Hilton Istanbul - } \\
\text { Old Town }\end{array}$ & Sultanahmet & 2104 \\
\hline 15 & Grand Hyatt Istanbul & Beşiktaş & 2066 \\
\hline 16 & InterContinental Istanbul & Taksim & 2039 \\
\hline 17 & Basileus Otel & Sultanahmet & 2001 \\
\hline 18 & Ottoman Hotel Imperial & Sultanahmet & 1878 \\
\hline 19 & $\begin{array}{l}\text { Best Western Plus The President } \\
\text { Hotel }\end{array}$ & Beyazıt & 1858 \\
\hline 20 & Orient Express Hotel & Sirkeci & 1833 \\
\hline 21 & $\begin{array}{l}\text { Four Seasons Hotel Istanbul at } \\
\text { Sultanahmet }\end{array}$ & Sultanahmet & 1797 \\
\hline 22 & Best Western Empire Palace & Sirkeci & 1786 \\
\hline 23 & $\begin{array}{l}\text { DoubleTree by Hilton Istanbul - } \\
\text { Moda }\end{array}$ & Moda & 1767 \\
\hline 24 & Titanic Business Kartal & Kartal & 1740 \\
\hline 25 & $\begin{array}{l}\text { Four Seasons Istanbul at the } \\
\text { Bosphorus }\end{array}$ & Besiktaş & 1721 \\
\hline
\end{tabular}

Note: In terms of the number of user comments on TripAdvisor.com.tr, the highest ranking was the "White House Hotel" in the Sultanahmet neighborhood, with a total of 4158 reviews, while the "Four Seasons Istanbul at the Bosphorus Hotel" in the Beşiktaş neighborhood was lowest in terms of the number of reviews. 
Annex B. Distribution of Number of Incoming Tourists to Turkey and Istanbul by Year (2017-2018)

\begin{tabular}{|c|c|c|c|c|c|c|}
\hline \multirow{2}{*}{ MONTH } & \multicolumn{2}{|c|}{ TURKEY } & \multicolumn{2}{|c|}{ ISTANBUL } & \multirow{2}{*}{$\begin{array}{c}\text { Change } \\
\text { Rate for } \\
2017 \\
\text { (Monthly) }\end{array}$} & \multirow{2}{*}{$\begin{array}{c}\text { Change } \\
\text { Rate for } \\
2017 \\
\text { (Cumulative }\end{array}$} \\
\hline & 2017 & 2018 & 2017 & 2018 & & \\
\hline January & $1,055,474$ & $1,461,570$ & 559,372 & 831,307 & 48.6 & 48.6 \\
\hline February & $1,159,833$ & $1,527,070$ & 590,175 & 848,510 & 43.8 & 46.1 \\
\hline March & $1,587,833$ & $2,139,766$ & 742,479 & $1,073,002$ & 44.5 & 45.5 \\
\hline April & $2,070,322$ & $2,655,561$ & 835,614 & $1,144,041$ & 36.9 & 42.9 \\
\hline May & $2,889,873$ & $3,678,440$ & 830,019 & 984,028 & 18.6 & 37.2 \\
\hline June & $3,486,940$ & $4,505,594$ & 827,494 & $1,100,389$ & 33 & 36.4 \\
\hline July & $5,075,961$ & $5,671,801$ & $1,319,549$ & $1,502,397$ & 13.9 & 31.2 \\
\hline August & $4,658,463$ & $5,383,332$ & $1,247,384$ & $1,561,033$ & 11.5 & 27.7 \\
\hline September & $4,076,630$ & $4,792,818$ & $1,045,896$ & $1,361,950$ & 18.1 & 26.4 \\
\hline October & $2,992,947$ & $3,755,467$ & $1,122,266$ & $1,230,079$ & 9.6 & 24.3 \\
\hline November & $1,652,795$ & $1,966,277$ & 831,982 & $1,015,032$ & 22 & 24.1 \\
\hline December & $1,703,789$ & $1,950,705$ & 888,365 & $1,077,979$ & 21.3 & 23.9 \\
\hline TOTAL & $32,410,860$ & $39,488,401$ & $10,840,595$ & $13,729,747$ & 27 & 35 \\
\hline
\end{tabular}

Note: According to Turkey Statistical Institute data, in 2018, the number of tourists visiting Istanbul increased by $\mathbf{2 4} \%$ on the same period of the previous year.

Annex C. Graphical Distribution of the Number of Tourists (Million) Visiting Istanbul by Years (2000-2018)

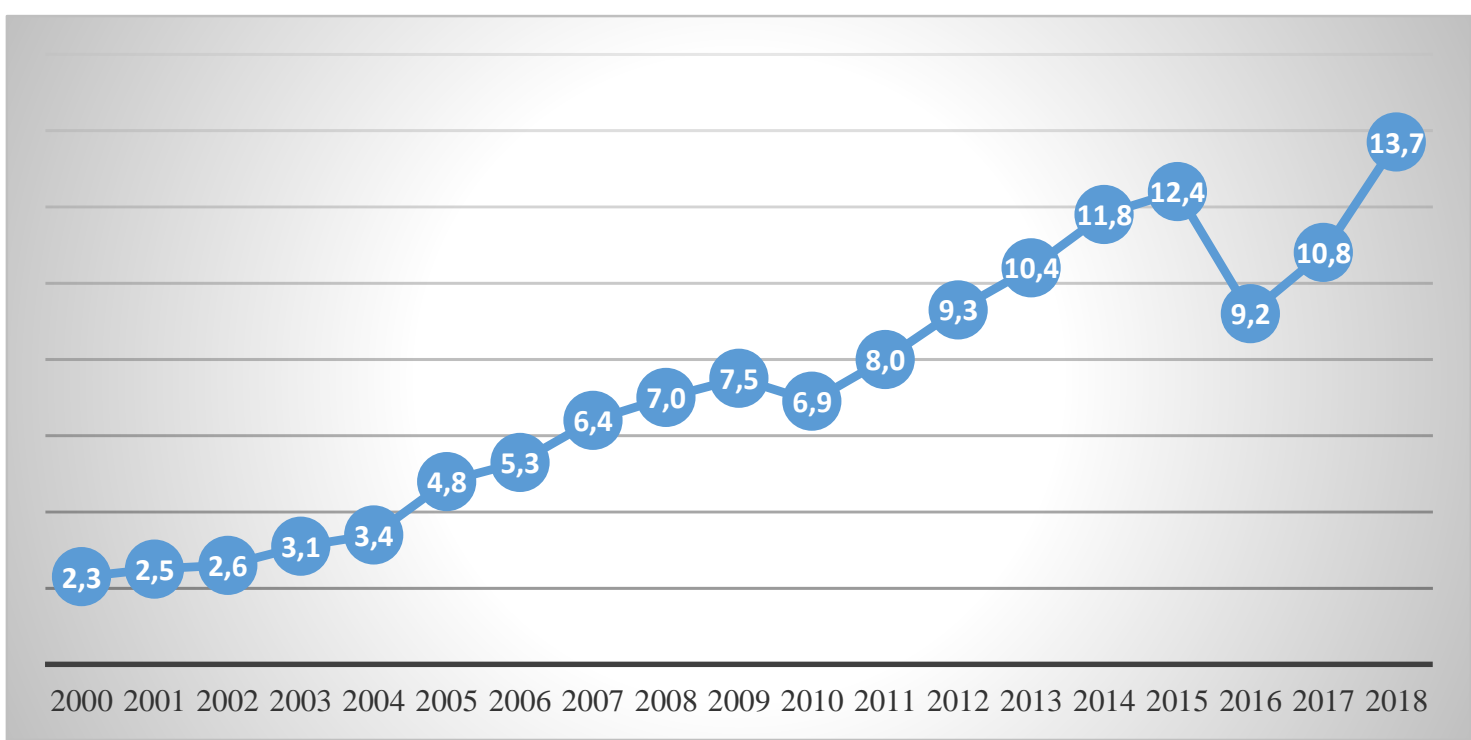

